Article

\title{
Empirical Research on the Relationship amongst Renewable Energy Consumption, Economic Growth and Foreign Direct Investment in Kazakhstan and Uzbekistan
}

\author{
Janusz Grabara ${ }^{1, *(D)}$, Arsen Tleppayev ${ }^{2}\left(\mathbb{D}\right.$, Malika Dabylova $^{3}$, Leonardus W. W. Mihardjo ${ }^{4(D)}$ and \\ Zdzisława Dacko-Pikiewicz ${ }^{5}$ (D)
}

1 The Management Faculty, Czestochowa University of Technology, 42-201 Czestochowa, Poland

2 Faculty of Economics and Business, Kazakh-German University, Pushkin St., 111, Almaty 050010, Kazakhstan; arsentlp@gmail.com

3 Higher School of Economics and Business, Al-Farabi Kazakh National University, 71 al-Farabi Ave., Almaty 050010, Kazakhstan; malika.dabylova@gmail.com

4 School of Business Management, Bina Nusantara University, Jalan Hang Lekir I No. 6, Senayan, Jakarta 10270, Indonesia; mihardjo@gmail.com

5 Faculty of Applied Sciences, WSB University, Zygmunta Cieplaka 1c, 41-300 Dabrowa Gornicza, Poland; zdacko@wsb.edu.pl

* Correspondence: janusz@grabara.eu

\section{check for}

updates

Citation: Grabara, J.; Tleppayev, A.; Dabylova, M.; Mihardjo, L.W.W.; Dacko-Pikiewicz, Z. Empirical

Research on the Relationship amongst Renewable Energy

Consumption, Economic Growth and Foreign Direct Investment in Kazakhstan and Uzbekistan. Energies 2021, 14, 332. https://doi.org/ 10.3390/en14020332

Received: 9 November 2020 Accepted: 6 January 2021 Published: 9 January 2021

Publisher's Note: MDPI stays neutral with regard to jurisdictional clai$\mathrm{ms}$ in published maps and institutional affiliations.

Copyright: (C) 2021 by the authors. Licensee MDPI, Basel, Switzerland. This article is an open access article distributed under the terms and conditions of the Creative Commons Attribution (CC BY) license (https:// creativecommons.org/licenses/by/ $4.0 /)$.

\begin{abstract}
In this contemporary era, environmental problems spread at different levels in all countries of the world. Economic growth does not just depend on prioritizing the environment or improving the environmental situation. If the foreign direct investment is directed to the polluting industries, they will increase pollution and damage the environment. The purpose of the study is to consider the relationship between foreign direct investment in Kazakhstan and Uzbekistan and economic growth and renewable energy consumption. The study is based on data obtained from 1992 to 2018. The results show that there is a two-way link between foreign direct investment and renewable energy consumption in the considered two countries. The Granger causality test approach is applied to explore the causal relationship between the variables. The Johansen co-integration test approach is also employed to test for a relationship. The empirical results verify the existence of co-integration between the series. The main factors influencing renewable energy are economic growth and electricity consumption. To reduce dependence on fuel-based energy sources, Kazakhstan and Uzbekistan need to attract energy to renewable energy sources and implement energy efficiency based on rapid progress. This is because renewable energy sources play the role of an engine that stimulates the production process in the economy for all countries.
\end{abstract}

Keywords: economic growth; Kazakhstan; Uzbekistan; FDI; energy consumption; $\mathrm{CO}_{2}$ emissions; electric power

\section{Introduction}

There is a consensus that Foreign Direct Investment (FDI) can ensure the growth of production and economy in a country. It stimulates the free movement of capital with the development of trade and creates environmental problems, one of the most critical issues recently. Attracting FDI as a way to stabilize the environment and develop the economy has spread rapidly around the world. It is typically regarded as a flow of information, technologies, and management processes to the host countries from the home countries of Multi-National Enterprises (MNEs) [1]. FDI has become increasingly crucial for the economic growth of a country with the accelerating rate of competition among nations, as it has a positive effect on the technical development of companies in the host countries through technology transfer [2]. Several studies have shown that FDI plays a significant role in host countries' economic development, particularly for those developing countries 
with well-developed financial markets [3,4]. FDI can also have indirect effects on renewable energy use as these international businesses are more likely to use efficient green energy methods.

Moreover, it is also believed that the development of renewable energy needs more enormous input of funds and technology and FDI can effectively provide the renewable energy industry with funds and technical support [5]. In addition, there is also evidence that certain foreign firms and countries also uphold high environmental standards [6,7]. Such foreign firms are more liable to use clean energy from renewable sources and energysaving practices.

Additionally, many scholars in the field of economics and energy have studied the relationship between energy consumption and economic growth. In particular, they found a strong link between economic growth and energy consumption. Economic growth in the country leads to an increase in energy consumption. According to Omri and Kahouli [8], the efficient use of energy requires a high level of the national economy. Besides, many scientific studies stated that the rate of economic growth in a country is directly related to the quality of capital accumulation in the country. The country's economic growth contributes to a spike in energy demand. The excessive energy demand and consumption leads to a large number of emissions of harmful substances into the environment. Streimikiene et al. [9] elaborated that the energy sector has the same impact on economic development and the environment. As environmental pollution increases, the ecological situation of the country poses several challenges to its natural resources [10]. In this scenario, there is also the probability of depletion of energy resources. Thus, massive efforts have been taken to utilize energy resources sustainably.

The decade spanning between the years 2014 and 2024 is named the "Decade of Sustainable Energy" for all by the United Nations. Sustainability of energy is likely to lead to broader access to clean energy production with low-carbon emissions, and increased investments in cleaner technology ultimately lead to a sustainable environment. The renewable share in electricity generation is projected to grow from $18.3 \%$ in 2002 to $39 \%$ by 2050, following the most ambitious scenarios developed by the International Energy Agency (IEA). Furthermore, renewable energies will play a critical role in lowering $\mathrm{CO}_{2}$ emissions by up to 50 per cent by 2050 [11]. Several studies have demonstrated that the use of energy resources is sensitive to economic growth. Chang et al. [12] have shown that renewable energy costs are susceptible to economic development countries.

In contrast, renewable energy pricing is less relevant for those countries characterized by low-cost growth. Van Vuuren et al. [13] also claimed that the extent of primary energy consumption indeed depends on technological and economic growth assumptions. Their conclusions suggest that rapid growth can boost energy requirements. In particular, economic development and energy consumption are closely related. On the other hand, there are also empirical results on the attraction of long-term significant foreign direct investment, the development of the stock market, and the positive impact of economic output on the consumption of clean energy. The development of the country's economy and its future is heavily reliant on the energy sector. According to Widiyanti et al. [14], energy is the only thing that can meet the country's development needs. The energy sector is of particular importance for the future development of the country, as it needs to develop as a competitive country and to sustain a stable economic dispute.

Long-term significant foreign direct investment and economic output positively influence the consumption of renewable energy. However, in case of Kazakhstan and Uzbekistan, the relationship among income, energy consumption, environmental pollution, and consumption of renewable energy has not gained much attention in the existing studies. Therefore, the present study attempts to examine the relationship between economic growth and renewable energy consumption and foreign direct investment and electric power consumption in Kazakhstan and Uzbekistan. It allows politicians in both countries to identify gaps in the implementation of environmental policies in the CIS (The Commonwealth of Independent States) through the integration of renewable energy and 
foreign direct investment. In Kazakhstan, which is directly dependent on minerals, all these conditions cause several difficulties and are reflected in real life. Increasing environmental investments require a comprehensive approach to overcoming existing obstacles. As a rule, only the simultaneous adoption of measures at the regulatory, economic, financial, and socio-political levels ensures the successful creation and subsequent improvement of the conditions for the activities of national and international investors to improve energy efficiency and introduce low-carbon technologies in a given country.

Furthermore, in the existing literature, energy consumption and economic growth nexus have been widely researched (e.g., Wolde-Rufael [15]; Costantini [16]; Bhattacharya [17]. Similarly, Chien and Hu [18] examined the impact of renewable energy on GDP using an expenditure approach. Their findings suggest that there is a positive relationship between renewable energy and GDP; however, on the flip side, economic growth and renewable energy studies are still scarce. The growing significance of renewables as a source of energy has created broad interest from both academics and energy policy analysts. Our contribution to the literature is as follows. First of all, this study, for the first time examines the relationship between GDP, FDI, and electric power consumption impact on renewable energy sources in Kazakhstan and Uzbekistan.

Given that the upgrading of the energy mix is vital and that FDI and economic growth are crucial to improve renewable energy development, comprehensive analysis of the relationship amongst the three variables is significant and reasonable. Secondly, since renewable energy production is actively increasing in many countries around the world, many questions about renewable energy production in Central and Eastern Europe, as well as in Central Asia and the Caucasus, remain unanswered [19]. More importantly, Kazakhstan, which is part of the CIS, is at the forefront of electricity production, followed by Uzbekistan. However, the role of renewable energy in excelling the respective economies has not been studied. Therefore, understanding the relationship among economic growth, renewable energy consumption, and foreign direct investment in Kazakhstan and Uzbekistan is a novel contribution. Moreover, the present study employs multiple statistical tests like unit root tests (Augmented Dickey-Fuller (ADF) and Phillips-Perron tests), Johansen co-integration test and Granger causality test, etc., (as discussed in Section 3) which is also an important contribution in the existing literature.

\section{Literature Review}

\subsection{Electricity Consumption and the Economy Indicators}

This section is an attempt to unveil the previous efforts of researchers regarding the concerned variables employed in the present analysis. There is scant literature on the role of renewable energy in understanding sustainable economic development. For instance, the bi-directional causation was identified between renewable energy use and economic growth by Sardosky [20] for 18 emerging economies. Sadorsky estimated that in the long term, a $1 \%$ rise in real income per capita raised the use of renewable energy per capita by approximately $3.5 \%$ for these economies. It was analyzed the sectoral causal association between renewable and non-renewable energy use and economic development in the US. Their results identified no causality between renewable energy consumption and real GDP in the commercial and industrial sectors. In contrast, positive uni-directional causality was found between residential renewable energy consumption and real GDP. According to Odhiambo [21], four methods relevant to renewable energy are already developed in the previous research works, the most important of which is the growth hypothesis.

On the contrary, some studies have investigated the association of renewable energy with economic growth and development. For instance, Ferroukhi et al. [22] analyzed the impact of renewable energy on global economic growth. The results of the study showed that expanding the use of renewable energy sources can help in creating competitive prices, meet the growing energy needs of a growing population, and ensure sustainable development. It can increase the productivity of natural resources and reduces emissions. Likewise, Apergis and Danuletiu [23] examined the relationship between renewable energy 
and economic growth based on indicators from 80 countries. The result showed that there is a two-way relationship between the use of renewable energy and economic growth, confirming the feedback hypothesis. In 2014, Leitao [24] investigated the relationship among globalization, renewable energy consumption, economic growth, and greenhouse gas emissions. The results showed a strong connection between economic growth and renewable energy consumption. Similar results were proven by Soava et al. [25] from their study conducted in $28 \mathrm{EU}$ countries. Ntanos et al. [26] evaluated the results of optimal communication in their research on European countries. Fang [27] evaluated the production functions of Cobb-Douglas production from 1978 to 2008 and proved that the use of renewable energy has a positive effect on the country's GDP growth. The results showed that $1 \%$ increase in renewable energy consumption increases the country's GDP by $0.12 \%$. Similarly, Lotz [28] studied the impact of renewable energy consumption on economic well-being using panel data methods. The results of his research showed that investments in renewable energy positively influence the economy and the environment.

The same phenomenon was assessed by Ihide and Ajazi [29] in the case of Nigeria between the years 1971 and 2013 using a semi-annual (quarterly) time series. The results showed that non-renewable energy consumption leads to an increase of $8 \%$ growth in the economy, while renewable energy consumption leads to a $19 \%$ increase. Likewise, Burakova and Freidin [30] investigated the positive relationship between economic growth and financial growth in Russia. In another study, Lee [31] examined the long-term and short-term use of renewable energy, emissions, and economic growth in the European Union from 1961 to 2012. The results of the study showed a positive relationship, both in the long and short term. Tiwari [32] studied the effects of renewable energy and nonrenewable energy in Europe and Eurasia. The outcome of his study showed that renewable energy consumption has a positive effect on GDP growth. Cetin [33] exhibited the same outcome from his study. Silva [34] confirmed the growth hypothesis, and his study was based on indicators from the United States, Denmark, Spain, and Portugal between 1960 and 2004. Marinash [35] conducted a study of Romania, Bulgaria, Hungary, Lithuania, and Slovenia and found that renewable energy consumption had similar results in terms of economic growth.

Furthermore, another important study is of Tsaurai and Ngcobo [36] on the relationship between renewable energy consumption and economic growth in Brazil, Russia, Knowledge of all three data analysis methods has also prevented the negative effects of renewable energy consumption and economic growth in Brazil, Russia, India, China, and South Africa. According to Dunn and Mutti [37] and Ozcicek and Agpak [38], the impact of education has been shown to increase renewable energy consumption and economic growth. The main goal was to promote the development of education in Brazil, Russia, India, China, and South Africa, thereby contributing to renewable energy consumption and economic growth. The results of the study do not coincide with the development of renewable energy consumption in Kazakhstan, which is rich in traditional energy sources (coal, gas, etc.). Many of the above studies showed different results.

In addition to the previous literature, the following studies deal with pollution related to energy consumption. Sarkodie and Strezov [39] in their study conducted between 1982 and 2016 in China, India, Iran, Indonesia, and South Africa. They found evidence that the economies of developed countries are increasing emissions of toxic gases into the air. They proposed the widespread use of technological advances in sustainable development policies as the main way to solve such problems. As a means to address environmental problems and achieve sustainable development, production and utilization of renewable energy resources are particularly critical [40].

In addition, in the context of renewable energy, recently Fan and Hao [40] investigated the relationships among renewables, foreign direct investment, and gross domestic product in 31 provinces in China from 2000 to 2015 along with foreign direct investment. It has been shown from empirical results that there is a long-term and stable association between per capita gross domestic product, per capita foreign direct investment, and per capita 
consumption of renewable energy. Furthermore, some country-specific studies include FDI in their analysis of energy consumption. A multitude of them finds evidence in favor of FDI-reducing energy intensity. In South Africa and Malaysia, Dube [41] and Foon Tang [42] described the co-integration between energy consumption and FDI. It is also proposed that there exists a two-way causal relation between FDI and energy consumption in Shanghai. Mudakkar et al. [43] find that causalities vary from energy consumption to FDI in Bangladesh and Sri Lanka, whereas causalities run from FDI to energy consumption for India.

Further, Azam et al. [44] stated that in Thailand, Malaysia, and Indonesia, both FDI and GDP are significantly related to energy consumption. None of these country-specific studies focused on FDI sector distribution. The connection of foreign direct investment (FDI) with the energy demand was examined by Doytch and Narayan [2]. FDI is a funding source that enables companies to grow. FDI can simultaneously be a driving force for promoting energy efficiency innovation.

Based on reviewing the literature, it is found that there is a dearth of studies exploring the effect of GDP, FDI, and electricity consumption on renewable energy generally and particularly in the context of Kazkhastan and Uzbakistan. The present study, in this case, will enrich the body of literature.

\subsection{An Empirical Study Based on Data from Kazakhstan and Uzbekistan}

While renewable energy production is actively increasing in many countries around the world, many questions, about renewable energy production in Central and Eastern Europe, as well as in Central Asia and the Caucasus, remain unanswered [19]. In particular, Kazakhstan, which is part of the CIS, is at the forefront of electricity producers. In second place is Uzbekistan (see Figure 1).

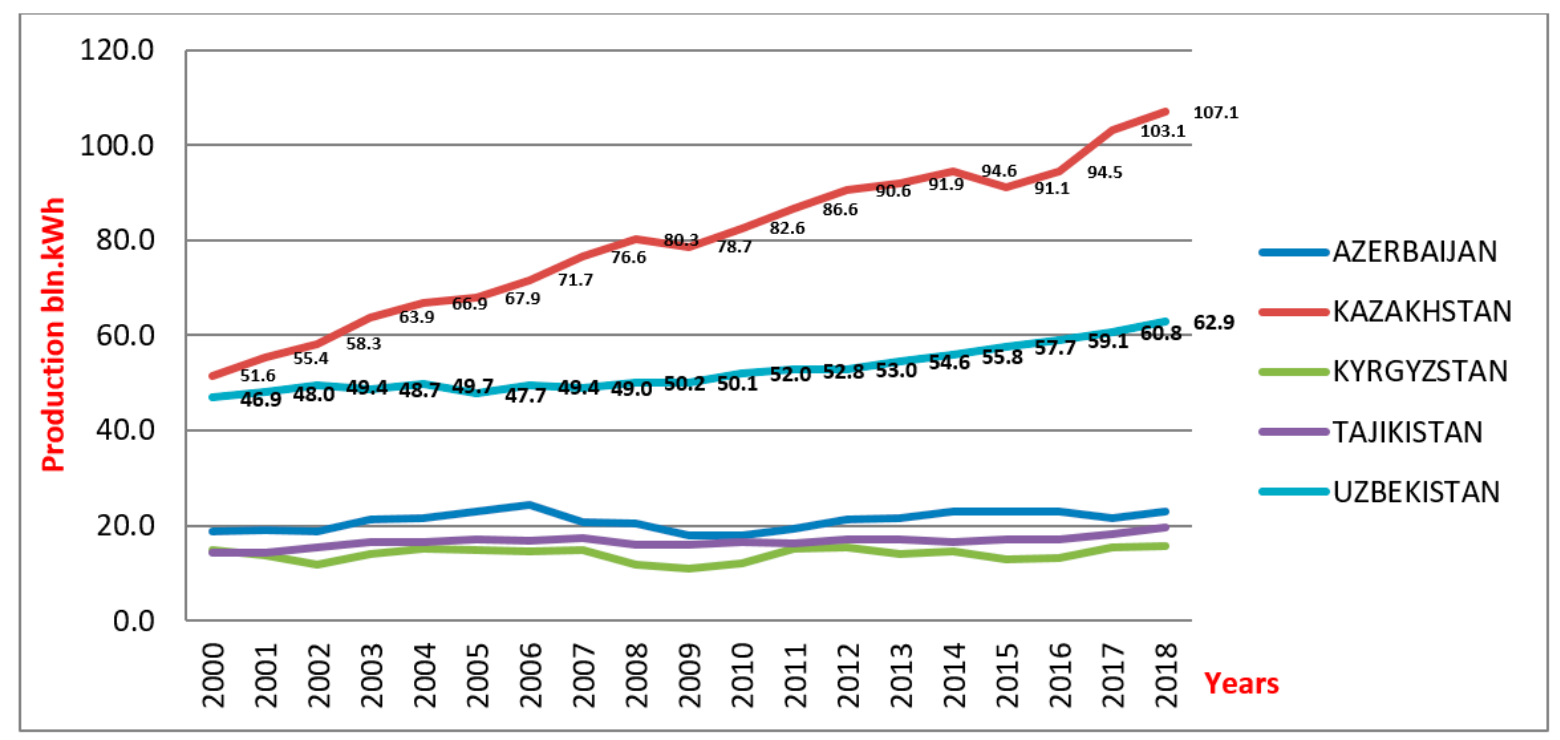

Figure 1. Production of electricity, bln. kWh.

Electricity consumption and $\mathrm{CO}_{2}$ emissions has been increasing due to the growth of the economy (per capita GDP increased from $\$ 1229$ in the 2000s to \$9812 in 2018), over the past decades. Since 1999, electricity consumption and $\mathrm{CO}_{2}$ emissions have been growing at a steady pace. Electricity consumption is marked by an average annual increase of $90 \mathrm{kWh}$ per resident for the period from 2001 to 2018 (Figure 2). 




Figure 2. Electric power consumption (kWh per capita).

Electricity production in Kazakhstan is carried out by 138 power stations, most of which are private. The total installed capacity of power plants is 21,902 MW. At the end of 2018, electricity generation was 106.8 billion $\mathrm{kWh}$ or $104.3 \%$ of the same period in 2017 ( 102.3 billion $\mathrm{kWh}$ ). Approximately $80 \%$ of electricity is produced in the north of the country, where coal mines are located. There is a shortage of electricity in the southern zone, with an excess in the northern zone. The deficit is because the population density in the southern zone is several times higher than in the northern one, due to the location of large megacities and settlements.

The installed capacity of Uzbekistan's power plants exceeds 14.1 million $\mathrm{kW}$ and accounts for about $50 \%$ of the generating capacity of the entire unified energy system of Central Asia. In 2017, Uzbekistan produced 60.7 billion kWh of electricity, which is an increase of $2.9 \%$ compared to 2016 . This is enough to meet the growing demand for electricity in the Republic to fulfil the obligations to supply electricity for export and maintain its energy security. All thermal and hydroelectric power stations are part of the structure of UzbekEnergo JSC. The basis of the energy system of Uzbekistan is thermal power plants with a total capacity of 12.1 million $\mathrm{kW}$. Five large thermal power plants have installed power units with a capacity of 150 to $800 \mathrm{MW}$. These are large thermal power plants such as Talimarjan, Syrdarya, Novo-Angren, and Tashkent, and they produce about $86 \%$ of electricity. In 2017, the thermal power plants of JSC "UzbekEnergo" produced 52.1 billion kWh of electric energy, and 7.3 million Gcal of thermal energy was released to consumers. Hydroelectric power stations of JSC "UzbekGidroenergo", depending on the water content of the year, generate about 6.5 billion $\mathrm{kW} / \mathrm{h}$ of electricity.

By providing additional generating capacity in the south, the system will become more balanced, and network losses will be reduced. To overcome difficulties with energy supply and reduce emissions, Kazakhstan's current policy is aimed at creating a more decentralized, balanced, and environmentally-friendly energy supply system that will include various types of RES. For Kazakhstan, coal remains the primary source of electricity production. Still, according to the concept of Kazakhstan's transition to a "green" economy by 2050, half of the country's total energy consumption should be generated by renewable energy sources. If we consider hydropower, the share of renewable energy generated in the total amount of electricity generated would be $10.2 \%$ in 2018 (data obtained from the Statistics Committee of the Ministry of National Economy of the Republic of Kazakhstan). Today, six large hydroelectric power plants with a total capacity of $2.5 \mathrm{GW}$ account for up to $10 \%$ of the total electricity production. The share of electricity from solar and wind power stations in 2019 reached 2.2\% from 0.2\% in 2015, and in 2020 this figure will reach 
$3 \%$, by $2025-6 \%$ and by $2030-10 \%$. The potential for generating electricity from solar energy in Kazakhstan is estimated at 3.9-5.4 TWh (mostly in the south), or about 5\% of annual energy consumption. In 2014, there were 26 operating facilities with an installed capacity of $178 \mathrm{MW}$. By the end of 2019, there were 87 facilities with a capacity of $1042 \mathrm{MW}$ in the country (WPP-283 MW, SES-529 MW, HPP-228 MW, BioES-2.4 MW), in 2020, the system will operate 108 facilities with a capacity of $1610 \mathrm{MW}$, and by the end of 2024, the renewable energy system will have at least $3000 \mathrm{MW}$ of power. Commissioning of a large number of facilities is planned for 2020. In Kazakhstan, on 4 July 2009, based on the adoption of the law "On Support of Renewable Energy Sources", the development of alternative energy was started. Following this law, the state assisted individual consumers in the amount of a $50 \%$ subsidy for the cost of a $5 \mathrm{~kW}$ unit. Macroeconomic indicators that can influence the growth of renewable electricity include economic growth (GDP), investment in the environment, and per capita electricity consumption. The use of renewable energy consumption is a major driving force in the process of urban development to achieve the goals of sustainable development. In this regard, Hanif et al. [45], in their work, showed the importance of foreign direct investment.

Table 1 provides data on the dynamics of the share of investments aimed at protecting the environment in the total investment volume over five years. Thus, the maximum indicator falls on 2014-1.6, and the minimum indicators mark the last two years for the specified period (Table 1$)$.

Table 1. Dynamics of the share of investments aimed at environmental protection and related to the green economy for Kazakhstan.

\begin{tabular}{ccccccc}
\hline & 2013 & 2014 & 2015 & 2016 & 2017 & 2018 \\
\hline $\begin{array}{c}\text { Share of investments aimed at } \\
\text { environmental protection in the } \\
\text { total investment volume, } \%\end{array}$ & 1.3 & 1.6 & 1.2 & 0.6 & 1.0 & 1.0
\end{tabular}

Source: compiled by the authors using statistical data from the Statistics Committee of the Ministry of the National Economy of Kazakhstan.

Among all investments aimed at protecting the environment in the total investment volume, the largest share is taken by investments in renewable energy sources, while investments in energy-saving technologies and improving energy efficiency are only $1.6 \%$, for the protection of atmospheric air and climate change problems- $9.3 \%$, the protection and rehabilitation of soil, underground, and surface water- $8.9 \%$, waste management$6.8 \%$, and wastewater treatment- $5.6 \%$.

Despite the growth in the share of investments, this indicator lags behind the level of developed countries. In the most prosperous countries, this figure reaches $3 \%$ of GDP. For example, European Union countries invest in green economy investments (climate change mitigation measures) $-1.2 \%$ of GDP, the United States of America- $1.3 \%$, and China-3.3\% of GDP. To achieve a clean economy with zero carbon emissions by 2050, the European Union aims to increase investment in its energy system and related infrastructure from about $2 \%$ to $3 \%$ of GDP, which will require the mobilization of private investment.

It is worth noting that in the world as a whole, there has been a pause in the shift of investment towards cleaner sources of energy supply. Investments in clean energy sources grew fastest in the energy sector. The share of clean energy sources in electricity generation investments in 2017 exceeded 70\%, compared to less than 50\% a decade ago. More spending on power grids and batteries also contributes to a more flexible energy system, which is crucial for increasing the share of wind and solar energy.

Although investments in transport and energy efficiency tend to increase gradually, investment in renewable energy and related network infrastructure tends to fall. Investment trends are influenced by inefficient market mechanisms, changes in fossil fuel prices, and subsidies. In the long run, the energy consumption with total petroleum products may 
link with economic growth (proxied by gross domestic product per capita in constant prices) [46].

Hypothesis 1 (H1). Economic growth is in positive relation to renewable energy output.

Hypothesis 2 (H2). FDI is in positive relation to renewable energy output.

\section{Methodology}

The methodology of the present study consists of the following steps.

Step 1 defines the goals of modelling, a set of factors and indicators involved in the model, selecting the general type of the model, including the composition and form of its constituent relationships.

Step 2 deals with a collection of necessary statistical information.

Step 3 investigates the statistical analysis of the model and, first of all, the statistical estimation of unknown model parameters.

Statistical techniques and tools: The data of this study will be analyzed using statistical techniques such as a Granger causality test, unit root test and Johansen co-integration test. The stationarity will be checked via an Augmented Dickey-Fuller (ADF) test whether the variables are classified as I (1). An Augmented Dickey-Fuller test (ADF) and Phillips-Perron test analyze the null hypothesis. A unit root is present in a time series sample. If all the variables are stationary on the first difference, the study will proceed with co-integration tests.

The Granger causality test is the procedure for checking the causal relationship between the series, in which one time series is the cause of changes in another according to Clive Granger, unlike regressions, which reflect "mere" correlations. In the Granger test, the authors tested two hypotheses: " $x$ does not Granger cause $y$ " and "y does not Granger cause $x^{\prime \prime}$.

To test whether there is a long-term equilibrium relationship between variables, it is necessary to perform co-integration tests on the variables.

Engle and Granger [47] determined that a linear combination of a non-stationary time series may be stationary. If such a stationary linear combination exists, then non-stationary time series are co-integrated.

According to Granger [48], co-integration means that two or more non-stationary variables are integrated in the same order with the stationary of residuals. Granger suggested that if two time series variables are not co-integrated, then there may be unidirectional or bidirectional Granger causality in the short run. In testing co-integration equations, Maddala and $\mathrm{Wu}$ [49] noted that the Fisher-type panel co-integration test using Johansen [50] test methodology is more efficient than using the Engle-Granger test method because the maximum likelihood procedure has significantly large and finite sample properties. The Johansen test allows hypotheses to be tested on the rank of co-integration (the number of linearly co-integrating vectors) and hypotheses on the form of co-integrating vectors.

Step 4 involves verification of the adequacy of the model and interpretation of the resulting model, a description of the results.

\section{Model shape selection}

The study aims to build a model based on data from two countries in accordance with previous studies.

The econometric model that has been constructed based on the objective of this research paper can be seen as follows:

$$
\mathrm{RW}=\mathrm{f}(\mathrm{GDP}, \mathrm{FDI}, \mathrm{ELP})
$$

where

- $\mathrm{RW}_{\mathrm{t}}$ represents renewable electricity output (\% of total electricity output)

- $\mathrm{GDP}_{\mathrm{t}}$ denotes economic growth as GDP per capita (current US\$)

- $\quad \mathrm{FDI}_{\mathrm{t}}$ depicts a foreign direct investment, net inflows (\% of GDP) 
- ELP reveals the electric power consumption (kWh per capita)

Renewable electricity output (\% of total electricity output) is the share of electricity generated from renewable sources (including hydroelectric power) in the total amount of electricity generated by all types of power plants.

RES means sources of energy that can be renewed by natural processes, including solar radiation energy, wind energy, hydrodynamic energy of water, and geothermal energy (heat of soil, groundwater, rivers, and water bodies). The 2020 plan for the production of renewable energy in Kazakhstan will amount to about 3 billion kWh. In 2019, Kazakhstan produced 2.4 billion kWh of green energy with an increase of $77.8 \%$ compared to the same period in 2018. Kazakhstan sets an ambitious goal to increase the share of renewable energy sources to $10 \%$ in the total volume of electricity production by 2030 , and by 2050 , taking into account alternative energy, to $50 \%$. Uzbekistan aims to increase the share of renewable energy sources (renewable energy sources) in the total volume of electricity production by $25 \%$ by 2030 .

The real GDP per capita is used to measure economic growth. According to the World Bank, in 2018, GDP per capita in Kazakhstan was \$9815 and in Uzbekistan \$1532.

FDI net inflows (\% of GDP) are used to measure FDI. Foreign direct investment is a net inflow of investments for the acquisition of a long-term share in the management (10 or more percent of voting shares) in an enterprise operating in an economy other than that of the investor.

According to the World Bank, in Kazakhstan, the highest value over the past 26 years was 13.01 in 2004, and the lowest was 0.12 in 2018. In Uzbekistan, the highest value over the past 26 years was 3.51 in 2010, and the lowest value was 0.18 in 1995 (1.24 in 2018).

ELP represents electric power consumption ( $\mathrm{kWh}$ per capita). Electric power consumption (kWh per capita) per capita electricity production by stations and less losses during transmission, distribution and conversion, and own use.

All of the variables were transformed into log-linear forms (LN). This transformation aims to obtain a model with elasticities of variables and reduce the sharpness of the time series data for consistent and reliable estimation [51]. The new transformation of the model in $\log$ form is as follows (as long-term equation):

$$
\operatorname{InRW}=\beta_{0}+\beta_{1} \operatorname{In~GDP}+\beta_{2} \operatorname{InFDI}+\beta_{3} \operatorname{InELP}+\varepsilon_{\mathrm{i}}
$$

$\varepsilon_{\mathrm{i}}$-error term assumed to be normally distributed with zero mean and constant variance.

\section{Results and Discussions}

\section{Unit root test:}

According to statistical tests, the data of all the series are nearly normally distributed. In Table 1, it can be identified that according to ADF and Phillips-Perron unit root tests, variables are non-stationary in their levels but become stationary after taking the first difference. Hence, it is concluded that all series are I (1) at the 5\% level of significance.

\section{Long-term equilibrium analysis: co-integration test:}

Co-integration among the variables is explored using the Johansen co-integration test, and the results are presented in Tables 2 and 3. 
Table 2. Unit root test.

\begin{tabular}{ccccccccc}
\hline & \multicolumn{2}{c}{ ADF } & \multicolumn{3}{c}{ Phillips-Perron Test } \\
\hline & \multicolumn{2}{c}{ Kazakhstan } & \multicolumn{2}{c}{ Uzbekistan } & \multicolumn{2}{c}{ Kazakhstan } & \multicolumn{2}{c}{ Uzbekistan } \\
\hline & $t$-Statistic & Prob. & $t$-Statistic & Prob. & $t$-Statistic & Prob. & $t$-Statistic & Prob. \\
\hline LNRW & -1.63 & 0.45 & -0.89 & 0.77 & 0.19 & 0.73 & -1.87 & 0.34 \\
\hline D(LNRW) & -5.46 & 0.00 & -9.01 & 0.00 & -4.01 & 0.00 & -9.47 & 0.00 \\
\hline LNGDP & -1.03 & 0.73 & -1.90 & 0.34 & 1.50 & 0.96 & -0.64 & 0.84 \\
\hline D(LNGDP) & -2.80 & 0.01 & -1.97 & 0.05 & -2.86 & 0.01 & -1.99 & 0.05 \\
\hline LNFDI & -2.20 & 0.21 & -4.57 & 0.00 & -1.13 & 0.23 & -4.66 & 0.00 \\
\hline D(LNFDI) & -6.54 & 0.00 & -8.07 & 0.00 & -4.53 & 0.00 & -21.99 & 0.00 \\
\hline LNELP & 0.70 & 0.86 & -1.17 & 0.21 & 0.35 & 0.78 & -0.68 & 0.41 \\
\hline D(LNELP) & -3.60 & 0.00 & -2.1 & 0.04 & -3.02 & 0.00 & -3.25 & 0.00 \\
\hline
\end{tabular}

Source: authors' calculation, using Eviews software.

Table 3. Co-integration test results.

\begin{tabular}{ccccccccc}
\hline & \multicolumn{4}{c}{ Kazakhstan } & & \multicolumn{3}{c}{ Uzbekistan } \\
\hline $\begin{array}{c}\text { Hypothesized No. } \\
\text { of CE(s) }\end{array}$ & $\begin{array}{c}\text { Trace } \\
\text { Statistic }\end{array}$ & Prob. & $\begin{array}{c}\text { Max-Eigen } \\
\text { Statistic }\end{array}$ & Prob. & Trace Statistic & Prob. & $\begin{array}{c}\text { Max-Eigen } \\
\text { Statistic }\end{array}$ & $\begin{array}{c}\text { Prob. } \\
\text { None }\end{array}$ \\
\hline$A_{t}$ most 1 & 45.277 & 0.014 & 29.729 & 0.008 & 44.375 & 0.018 & 24.190 & 0.049 \\
\hline$A_{t}$ most 2 & 15.547 & 0.413 & 10.203 & 0.4648 & 20.185 & 0.151 & 13.262 & 0.211 \\
\hline$A_{t}$ most 3 & 5.344 & 0.520 & 5.036 & 0.4728 & 6.923 & 0.333 & 6.825 & 0.265 \\
\hline
\end{tabular}

* indicates 1 co-integrating eqn(s) at the 0.05 level. Source: authors' calculation, using Eviews software.

These results are the stable relationship among renewable energy, GDP per capita, FDI inflows, and total electric power consumption per capita. According to Table 2, the statistical $p$-values are less than $5 \%$ the null hypothesis of co-integration equation and at most 1 for the co-integration equation.

The results of calculations show that electric power consumption (kWh per capita) has a significant impact on the growth of the share of renewable energy. This fact may be due to increased consumption, which can only be satisfied by the availability of alternative sources in densely populated areas with no traditional energy sources.

The coefficient of LNELP is positive as 0.624 and statistically significant as its absolute $t$-value is 16.865 for Kazakhstan. The coefficient and $t$-value for Uzbekistan are 0.209 and 2.488, respectively (Table 4).

Table 4. Long-term equation with $\ln R W$ as a dependent variable.

\begin{tabular}{ccccccc}
\hline & \multicolumn{3}{c}{ Kazakhstan } & \multicolumn{3}{c}{ Uzbekistan } \\
\hline Variable & Coefficient & $\begin{array}{c}\text { Standard } \\
\text { Error }\end{array}$ & $\boldsymbol{t}$-Statistic & Coefficient & $\begin{array}{c}\text { Standard } \\
\text { Error }\end{array}$ & $\boldsymbol{t}$-Statistic \\
\hline LNGDP & -0.292 & 0.060 & -4.867 & 0.163 & 0.093 & 1.753 \\
\hline LNFDI & -0.217 & 0.032 & -6.781 & -0.074 & 0.015 & -4.933 \\
\hline LNELP & 0.624 & 0.037 & 16.865 & 0.209 & 0.084 & 2.488 \\
\hline
\end{tabular}

Source: authors' calculation, using Eviews software.

For Kazakhstan, the coefficient of GDP per capita suggests that a $1 \%$ increase in per capita GDP will lead to a decrease in the renewable share by $0.29 \%$ (negative growth hypothesis). This fact is due to the raw nature of the development of the country's economy. 
Rising prices for export energy resources such as oil and gas lead to an increase in GDP while reducing investment incentives for the transition to green energy. For Uzbekistan, the authors accepted the neutrality hypothesis because the variable is statistically insignificant.

For Kazakhstan, the coefficient of foreign direct investment and net inflows suggest that a $1 \%$ increase in a variable will lead to a decrease in the renewable share by $0.22 \%$. For Uzbekistan, it will lead to a decrease in the renewable share by $0.07 \%$. This fact may also be due to the main sector for attracting investment, mining, which reduces the incentive to invest in long-term, profitable renewable energy projects.

After finding one co-integrating equation among the variables, the study estimated a Vector Error Correction (VEC) model. As stated previously, in a VEC model, there are two possible sources of causality: error correction term, which shows long-run causality, and lagged explanatory variables, revealing short-run causality.

The VEC model is shown in Table 5.

Table 5. Vector Error Correction models.

\begin{tabular}{ccccccc}
\hline & \multicolumn{3}{c}{ Kazakhstan } & \multicolumn{3}{c}{ Uzbekistan } \\
\hline Variable & Coefficient & $\begin{array}{c}\text { Standard } \\
\text { Error }\end{array}$ & $t$-Statistic & Coefficient & $\begin{array}{c}\text { Standard } \\
\text { Error }\end{array}$ & $t$-Statistic \\
\hline$\Delta$ LNGDP & -0.308 & 0.024 & -12.66 & 0.129 & 0.044 & 2.95 \\
\hline$\Delta$ LNFDI & -0.29 & 0.083 & -3.50 & -0.042 & 0.009 & -4.6 \\
\hline$\Delta$ LNELP & 0.678 & 0.031 & 21.60 & 0.247 & 0.039 & 6.256 \\
\hline Source: authors' calculation, using Eviews software. & & & &
\end{tabular}

The researchers examined whether there are autocorrelation and heteroscedasticity in the model. Moreover, the normality of the model was tested. It can be concluded from the test results that the VEC model residual passes all diagnostic tests. An assumption of the VEC model is that residuals are distributed normally. To verify this, the authors used VEC residual normality tests (according to orthogonalization: Cholesky criterion), also validating the fulfillment of this assumption at a significance level: $=0.05$. Regarding the assumption of homokedasticity of residuals, to verify it, the white heteroskedasticity test was used at significance level $\alpha=0.05$; the estimated VEC model also fulfills the assumption of homoscedasticity of residuals (Table 6).

Table 6. Diagnostic tests of VEC model residual.

\begin{tabular}{ccccc}
\hline & Kazakhstan & \multicolumn{3}{c}{ Uzbekistan } \\
\cline { 2 - 5 } & Test Statistic & $p$-Value & Test Statistic & $p$-Value \\
\hline Serial correlation LM test & 15.63 & 0.48 & 12.75 & 0.69 \\
\hline White heteroskedacity test & 176.62 & 0.56 & 187.71 & 0.33 \\
\hline Normality test & 6.4 & 0.6 & 16.29 & 0.04 \\
\hline
\end{tabular}

The present study has also used the AR root stability test. The estimated model will be assumed to be stable if all roots fall within the circle. Figure 3 shows that the model of Kazakhstan and Uzbekistan is stable since the polynomial roots fall within the unit circle. 
Inverse Roots of AR Characteristic Polynomial

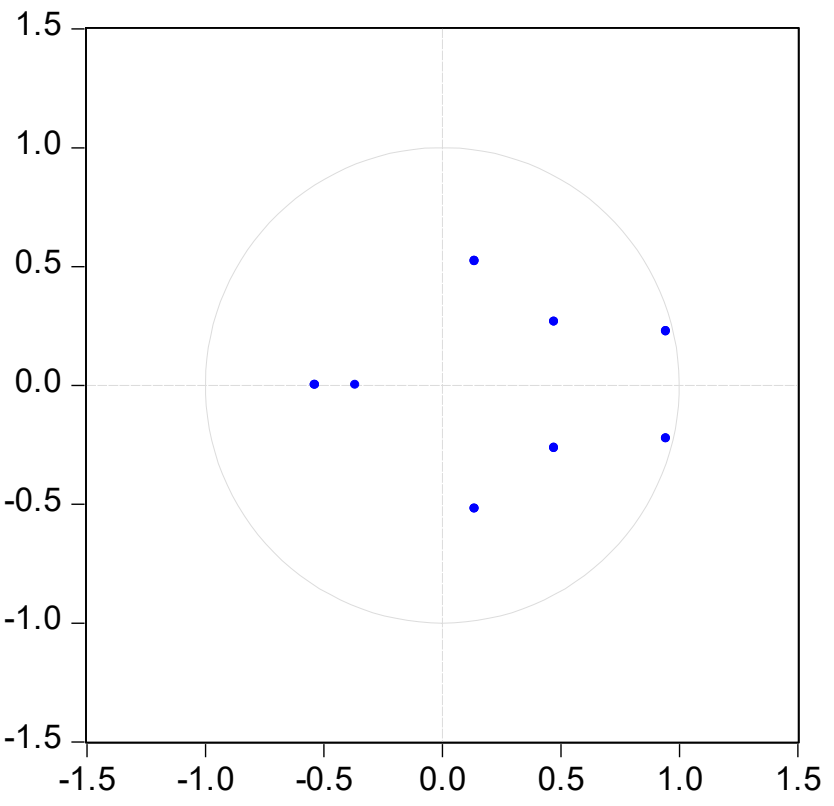

Uzbekistan
Inverse Roots of AR Characteristic Polynomial

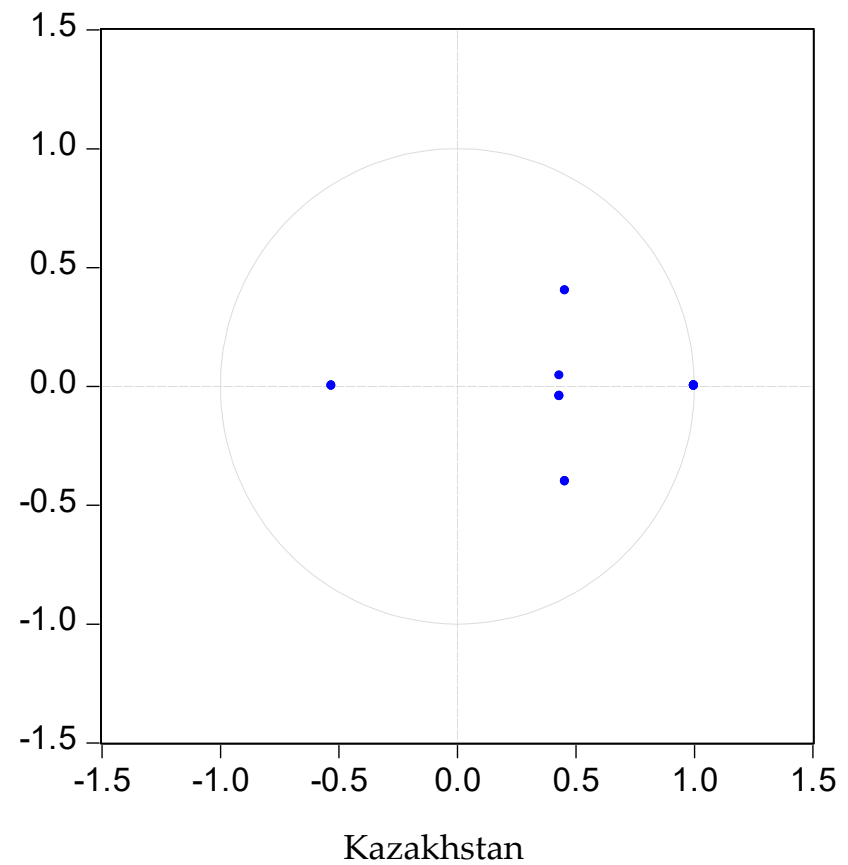

Figure 3. Graph of AR inverse root.

The researchers used the impulse response functions and the forecast variance decomposition functions to investigate the dynamic relations between the variables.

Figure 4 shows the impulse response function result of economic growth (GDP), Foreign Direct Investment (FDI) and electric power consumption (ELP) over 10 years.

For Uzbekistan, the diagram reveals that renewable energy responded positively to shocks in GDP up to the ninth period; the degree of impact reaches the largest in the fourth year. For Kazakhstan, the diagram reveals that renewable energy responded negatively to shocks in GDP; the degree of impact reaches the largest in the fourth year.

For Uzbekistan, the diagram reveals that renewable energy responded positively to shocks in FDI and reached a peak in the third year. For Kazakhstan, the diagram reveals that renewable energy responded negatively to shocks in FDI and reached a peak negatively in the third year.

For Uzbekistan, the diagram reveals that renewable energy responded negatively to shocks in electric power consumption, reaching a peak negatively in the second year. For Kazakhstan, the diagram reveals that renewable energy responded positively to shocks in electric power consumption up to the second year, then began to decrease, reaching peaks negatively in the fourth and fifth year, and then began to increase in the seventh year.

The variance decomposition determines how much of the forecasted error variance of each of the variables can be explained by the exogenous shocks of other variables. From Table 7 for Uzbekistan, below renewable energy was largely driven by itself, significantly ranging from $100 \%$ to $89 \%$. Electric power consumption, which appeared as the second driver, contributed about $16 \%$ to variations in the first period and decreased up to $7 \%$. Foreign Direct Investment (FDI) contributed about $5 \%$ to variations in the first period and GDP contributed $2.3 \%$. 

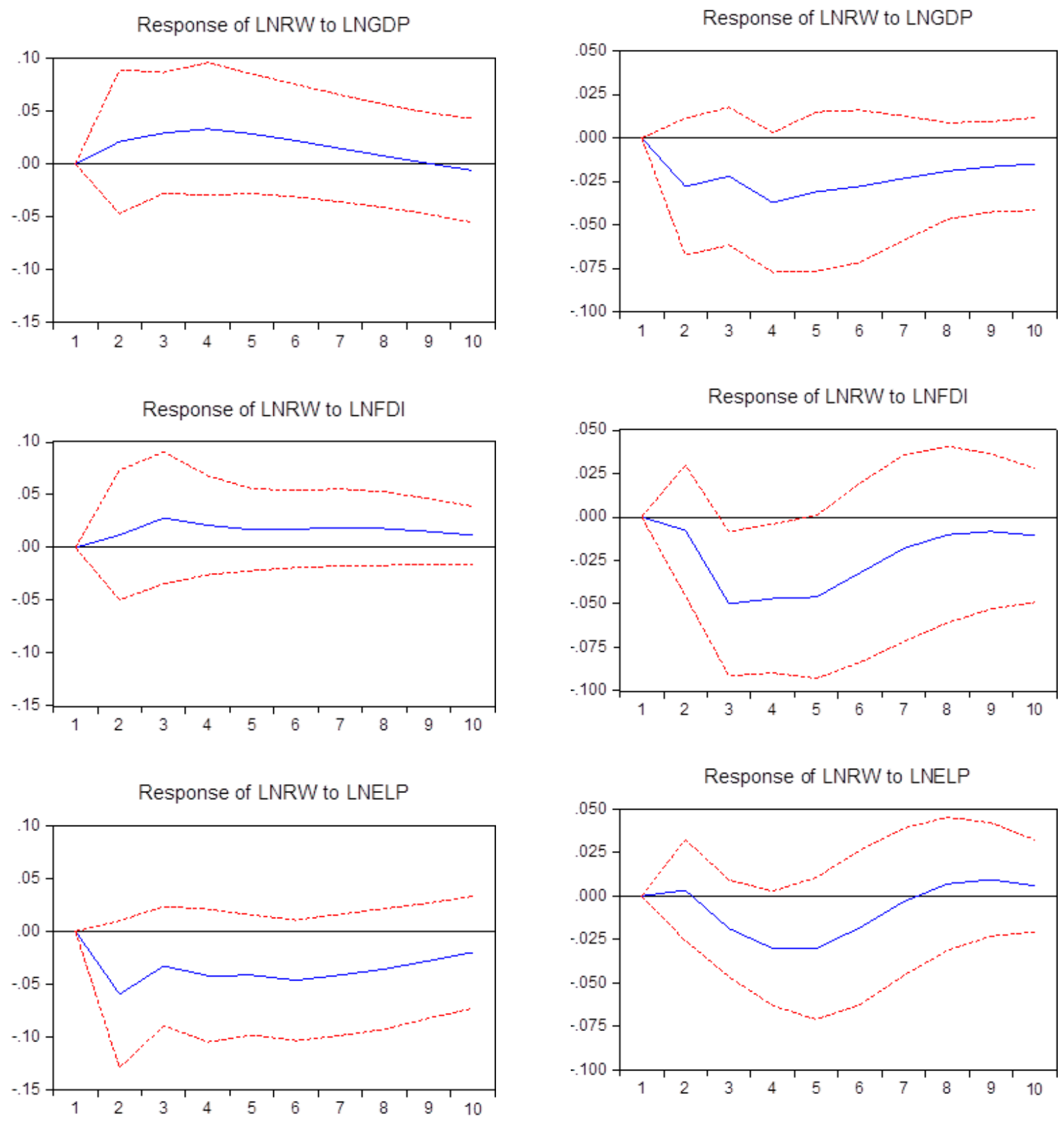

Uzbekistan

\section{Kazakhstan}

Figure 4. Impulse response function graphs.

Table 7. Results of variance decomposition analysis (Uzbekistan).

\begin{tabular}{cccccc}
\hline Period & S.E. & LNRW & LNGDP & LNFDI & LNELP \\
\hline 1 & 0.133774 & 100.0000 & 0.000000 & 0.000000 & 0.000000 \\
\hline 2 & 0.182362 & 76.97973 & 2.314995 & 4.886449 & 15.81883 \\
\hline 3 & 0.211184 & 82.42024 & 1.947095 & 3.805809 & 11.82686 \\
\hline 4 & 0.241442 & 81.94931 & 1.873925 & 3.538111 & 12.63865 \\
\hline 5 & 0.263616 & 84.40142 & 1.613786 & 3.373256 & 10.61154 \\
\hline 6 & 0.284553 & 85.33870 & 1.597290 & 2.935858 & 10.12815 \\
\hline 7 & 0.305254 & 86.81205 & 1.402986 & 2.849376 & 8.935583 \\
\hline
\end{tabular}


Table 7. Cont.

\begin{tabular}{cccccc}
\hline Period & S.E. & LNRW & LNGDP & LNFDI & LNELP \\
\hline 8 & 0.323404 & 87.70000 & 1.347483 & 2.650436 & 8.302078 \\
\hline 9 & 0.341245 & 88.67560 & 1.243763 & 2.494196 & 7.586442 \\
\hline 10 & 0.358285 & 89.35873 & 1.176895 & 2.386862 & 7.077515 \\
\hline
\end{tabular}

The results imply that the predominant source of variation in renewable electricity output in Uzbekistan is electric power consumption, while GDP accounts for a very low variation.

From Table 8 for Kazakhstan, below renewable energy was largely driven by itself, significantly ranging from $100 \%$ to $75 \%$. FDI, which appeared as the second driver, contributed about $54 \%$ to variations in the second period and decreased up to $33 \%$ in six periods. GDP contributed about $20 \%$ to variations in the nine periods and electric power consumption contributed $4 \%$ in 10 periods.

Table 8. Results of variance decomposition analysis (Kazakhstan).

\begin{tabular}{cccccc}
\hline Period & S.E. & LNRW & LNGDP & LNFDI & LNELP \\
\hline 1 & 0.066461 & 100.0000 & 0.000000 & 0.000000 & 0.000000 \\
\hline 2 & 0.139480 & 74.57884 & 7.382889 & 18.03765 & 0.000623 \\
\hline 3 & 0.218331 & 41.97262 & 4.011027 & 53.86992 & 0.146431 \\
\hline 4 & 0.236900 & 40.49345 & 8.088901 & 50.75553 & 0.662111 \\
\hline 5 & 0.287655 & 43.48081 & 18.06079 & 37.13901 & 1.319395 \\
\hline 6 & 0.357512 & 47.34907 & 16.90621 & 33.38080 & 2.363925 \\
\hline 7 & 0.446579 & 32.77689 & 11.58322 & 53.00685 & 2.633041 \\
\hline 8 & 0.458087 & 31.30578 & 14.74292 & 50.69972 & 3.251587 \\
\hline 9 & 0.540265 & 30.04376 & 20.00354 & 46.67992 & 3.272779 \\
\hline 10 & 0.619271 & 35.72248 & 18.07810 & 42.24685 & 3.952573 \\
\hline
\end{tabular}

The results imply that the predominant source of variation in renewable electricity output in Kazakhstan is foreign direct investment, while electric power consumption accounts for a very low variation.

Through the Granger causality test, we can analyze the causal relationship amongst renewable energy output, FDI (\% of GDP), electric power consumption, and GDP per capita as if they are not co-integrated. The results of the Granger test are presented in Table 9.

Table 9. Pairwise Granger causality tests.

\begin{tabular}{ccccc}
\hline & \multicolumn{2}{c}{ Kazakhstan } & \multicolumn{2}{c}{ Uzbekistan } \\
\hline Null Hypothesis & F-Statistic & Prob. & F-Statistic & Prob. \\
\hline LNGDP does not Granger cause LNRW & 9.05833 & 0.0016 & 0.42117 & 0.6623 \\
\hline LNFDI does not Granger cause LNRW & 6.69499 & 0.0059 & 0.56825 & 0.5759 \\
\hline LNELP does not Granger cause LNRW & 3.05267 & 0.0697 & 2.91269 & 0.0788 \\
\hline
\end{tabular}

Note: The conclusions in this table are judged at a significance level of $10 \%$. Source: authors' calculation, using Eviews software.

Pairwise Granger causality tests confirm the results of the Johansen co-integration test.

In an effort to determine the short-run causality among the variables, Granger causality/block exogeneity Wald tests based upon the VEC model are performed. According to 
the test results, short-run causality is confirmed in our previous pairwise Granger causality test results (Table 10).

Table 10. VEC Granger causality/block exogeneity Wald tests.

\begin{tabular}{ccccc}
\hline & \multicolumn{3}{c}{ Dependent Variable: D (LNRW) } \\
\hline & \multicolumn{2}{c}{ Kazakhstan } & \multicolumn{2}{c}{ Uzbekistan } \\
\cline { 2 - 5 } & Chi-sq & Prob. & Chi-sq & Prob. \\
\hline D(LNGDP) & 10.25466 & 0.0165 & 0.294009 & 0.8633 \\
D(LNFDI) & 11.83287 & 0.0080 & 0.100095 & 0.9512 \\
D(LNELP) & 7.872952 & 0.0487 & 7.311944 & 0.0258 \\
\hline
\end{tabular}

There is a causal relationship between electric power consumption ( $\mathrm{kWh}$ per capita) and renewable electricity output (\% of total electricity output) for the two countries. For Kazakhstan, there is also the impact of GDP per capita and foreign direct investment and net inflows (\% of GDP) on renewable electricity output ( $\%$ of total electricity output). For Uzbekistan, the impact of these two variables on the share of renewable energy is not observed. Findings from long-run output elasticities indicate that renewable energy consumption has a significant positive impact on the economic output for $57 \%$ [52].

In Kazakhstan, the negative impact of GDP on renewable energy consumption is related to the resource-based nature of the economy, in which the increase in production of cheap fossil fuels does not stimulate the transition to as yet expensive renewable energy sources. The negative impact of foreign investment in both countries is due to the lack of investment incentives for the introduction of renewable energy stations and a clear legal regime that would protect the rights of the investor and prescribe requirements, conditions for connecting to the network, and the sale of energy produced by independent energy companies. At the moment, Uzbekistan and Kazakhstan have just started implementing investment and legislative incentives for switching to clean energy sources, and most of the investments are still aimed at financing the production and use of traditional sources. Uzbekistan adopted a law on the use of renewable energy sources on 16 April 2019. Kazakhstan introduced an auction mechanism aimed at selecting the most effective renewable energy projects at the lowest prices [53].

Low-carb energy requires the introduction of improved energy efficiency, new technologies, and the development of renewable energy sources. According to Lee [54], when significant efforts are made to attract FDI through political campaigns, the environment wins. The feedback effect between foreign direct investment and energy consumption is identified using causality analysis. Short-run Granger causality tests highlighted unidirectional causality running from renewable energy consumption to $\mathrm{CO}_{2}$ emissions, indicating the pivotal role of renewable energy in reducing emissions [55]. Sbia [56] and Čulková et al. [57] show that foreign direct investment, energy consumption, carbon emissions, clean energy, and economic growth are the reasons for open trade.

\section{Conclusions}

Energy is a source of economic growth via energy consumption, as well as a significant problem via $\mathrm{CO}_{2}$ emissions. This article summarizes the data on FDI, REC, and economic growth in Kazakhstan and Uzbekistan. The relationship among REC, FDI, and economic growth in Kazakhstan and Uzbekistan is determined by indicators for the period from 1992 to 2018. The pairwise Granger causality tests indicate that there are significant longrun causalities from the variables of renewable energy consumption and foreign direct investments. Increased electricity consumption leads the share of renewable energy extenssion. The relationship of economic growth with renewable energy consumption accepts a negative growth hypothesis for Kazakhstan and neutrality for Uzbekistan. Foreign direct investment negatively affects the share of renewable energy, which may be because raw materials such as coal, oil, and gas remain the main investment sector. 
Policy plays a key role in solving the problems of transition to sustainable energy consumption, stimulating investments in clean technologies, which are necessary for decarbonization of the economy [58-61]. Climate project financing needs to be improved to ensure that infrastructure activities are resilient to the effects of climate change. Lowcarbon technologies, which are still new and risky, and policies and economic incentives can complement market-based instruments to stimulate investment in clean energy.

The payback period of projects in the field of renewable energy will remain relatively high due to a significant difference in the cost of kWh of energy, unlike coal or gas stations. Moreover, more than $40 \%$ of all stations in Kazakhstan need modernization and updating. In this regard, long-term financing for renewable energy projects remains almost inaccessible. Financing comes only through international financial institutions and at a rate of interest of $12-13 \%$ per annum, which exceeds the global figures.

Currently, Kazakhstan and Uzbekistan aim to move from a raw materials economy to an economy of new technologies, which is also reinforced by the obsolescence of current production technologies. In Kazakhstan, according to experts, the potential of solar energy is estimated at 4 billion $\mathrm{kWh}$ per year, and in Uzbekistan, it makes up $98.5 \%$ of all renewable energy sources combined. In addition, the potential of wind energy is estimated at 322 billion kWh per year in Kazakhstan.

Therefore, the investment policy should be aimed at modernizing the industrial structure through the transition to green energy and the development of renewable energy. At the moment, the benefits from the export of commodities have not led to the stimulation of renewable energy sources (negative growth hypothesis for Kazakhstan and neutrality for Uzbekistan).

Governments can provide public finance and strategic roadmaps for infrastructure development. These proposals enable the introduction and integration of renewable energy and low-carbon technologies such as electric cars, smart appliances, and solar panels. It is also necessary to subsidize low-carbon technologies, which are prohibitively expensive for some low-income groups.

Furthermore, the governments of Kazakhstan and Uzbekistan should stimulate the flow of foreign direct investment in renewable energy, using the experience of countries that have advantages in renewable energy sources.

Countries will have to develop a state wide-scale industry development program, which includes technological, financial, administrative, and other resources necessary for the industry.

Author Contributions: Conceptualization, A.T. and M.D.; methodology, A.T.; validation, A.T., and L.W.W.M.; formal analysis, Z.D.-P.; investigation, M.D.; data curation, A.T.; writing-original draft preparation, A.T. and J.G.; writing-review and editing, L.W.W.M. and M.D.; supervision, Z.D.-P.; project administration, J.G.; funding acquisition, J.G. and Z.D.-P. All authors have read and agreed to the published version of the manuscript.

Funding: This research received no external funding.

Institutional Review Board Statement: Not applicable.

Informed Consent Statement: Not applicable.

Data Availability Statement: Not applicable.

Conflicts of Interest: The authors declare no conflict of interest.

\section{References}

1. Nakicenovic, N.; Swart, R. (Eds.) Emissions Scenarios; Cambridge University Press: Cambridge, UK, 2000.

2. Doytch, N.; Narayan, S. Does FDI influence renewable energy consumption? An analysis of sectoral FDI impact on renewable and non-renewable industrial energy consumption. Energy Econ. 2016, 54, 291-301. [CrossRef]

3. Kotrajaras, P.; Tubtimtong, B.; Wiboonchutikula, P. Does FDI enhance economic growth? New evidence from East Asia. ASEAN Econ. Bull. 2011, 28, 183-202. [CrossRef] 
4. Azman-Saini, W.N.W.; Law, S.H.; Ahmad, A.H. FDI and economic growth: New evidence on the role of financial markets. Econ. Lett. 2010, 107, 211-213. [CrossRef]

5. Brunnschweiler, C.N. Finance for renewable energy: An empirical analysis of developing and transition economies. Environ. Dev. Econ. 2010, 15, 241-274. [CrossRef]

6. Eskeland, G.S.; Harrison, A.E. Moving to greener pastures? Multinationals and the pollution haven hypothesis. J. Dev. Econ. 2003, 70, 1-23. [CrossRef]

7. Doytch, N.; Uctum, M. Globalization and the environmental spillovers from sectoral FDI. 2015; Unpublished work.

8. Omri, A.; Kahouli, V. Causal relationships between energy consumption, foreign direct investment and economic growth: Fresh evidence from dynamic simultaneous-equations models. Energy Policy 2014, 67, 913-922. [CrossRef]

9. Štreimikienè, D.; Mikalauskienè, A.; Mikalauskas, I. Comparative assessment of sustainable energy development in the Czech Republic, Lithuania and Slovakia. J. Compet. 2016, 8, 31-41.

10. Haseeb, M.; Kot, S.; Iqbal-Hussain, H.; Jermsittiparsert, K. Impact of economic growth, environmental pollution, and energy consumption on health expenditure and R\&D expenditure of ASEAN countries. Energies 2019, 12, 3598.

11. IEA. World Energy Outlook; OECD/IEA: Paris, France, 2009.

12. Chang, T.H.; Huang, C.M.; Lee, M.C. Threshold effect of the economic growth rate on the renewable energy development from a change in energy price: Evidence from OECD countries. Energy Policy 2009, 37, 5796-5802. [CrossRef]

13. Van Vuuren, D.P.; Riahi, K.; Moss, R.; Edmonds, J.; Thomson, A.; Nakicenovic, N.; Kram, T.; Berkhout, F.; Swart, R. A proposal for a new scenario framework to support research and assessment in different climate research communities. Glob. Environ. Chang. 2012, 22, 21-35. [CrossRef]

14. Widiyanti, M.; Sadalia, I.; Zunaidah, Z.; Irawati, N.; Hendrawaty, E. Determining firm's performance: Moderating role of CSR in renewable energy, sector of Indonesia. Pol. J. Manag. Stud. 2019, 19, 432-441.

15. Wolde-Rufael, Y. Energy consumption and economic growth: The experience of African countries revisited. Energy Econ. 2009, 31, 217-224. [CrossRef]

16. Costantini, V.; Martini, C. The causality between energy consumption and economic growth: A multi-sectoral analysis using non-stationary cointegrated panel data. Energy Econ. 2010, 32, 591-603. [CrossRef]

17. Bhattacharya, M.; Rafiq, S.; Bhattacharya, S. The role of technology on the dynamics of coal consumption-economic growth: New evidence from China. Appl. Energy 2015, 154, 686-695. [CrossRef]

18. Chien, T.; Hu, J.L. Renewable energy: An efficient mechanism to improve GDP. Energy Policy 2008, 36, 3035-3042. [CrossRef]

19. Przychodzen, W.; Przychodzen, J. Determinants of renewable energy production in transition economies: A panel data approach. Energy 2020, 191, 116583. [CrossRef]

20. Sadorsky, P. Renewable energy consumption and income in emerging economies. Energy Policy 2009, 37, 4021-4028. [CrossRef]

21. Odhiambo, N. Electricity consumption and economic growth in South Africa: A trivariate causality test. Energy Econ. 2009, 31, 635-640. [CrossRef]

22. Ferroukhi, R.; Lopez-Peña, A.; Kieffer, G.; Nagpal, D.; Hawila, D.; Khalid, A.; El-Katiri, L.; Vinci, S.; Fernandez, A. Renewable Energy Benefits: Measuring the Economics; IRENA: Abu Dhabi, United Arab Emirates, 2016; pp. 10-92.

23. Apergis, N.; Danuletiu, D.C. Renewable energy and economic growth: Evidence from the sign of panel long-run causality. Int. J. Energy Econ. Policy 2014, 4, 578-587.

24. Leitao, N.C. Economic growth, carbon dioxide emissions, renewable energy and globalization. Int. J. Energy Econ. Policy 2014, 4 , 391-399.

25. Soava, G.; Mehedintu, A.; Sterpu, M.; Raduteanu, M. Impact of renewable energy consumption on economic growth: Evidence from European Union Countries. Technol. Econ. Dev. Econ. 2018, 24, 914-932. [CrossRef]

26. Ntanos, S.; Skordoulis, M.; Kyriakopoulos, G.; Arabatzis, G.; Chalikias, M.; Galatsidas, S.; Batzios, A.; Katsarou, A. Renewable energy and economic growth: Evidence from European countries. Sustainability 2018, 10, 2626. [CrossRef]

27. Fang, Y. Economic welfare impacts from renewable energy consumption: The China experience. Renew. Sustain. Energy Rev. 2011, 15, 5120-5128. [CrossRef]

28. Lotz, R.I. The Impact of Renewable Energy Consumption to Economic Welfare: A Panel Data Application; Working Paper; Department of Economics University of Pretoria: Pretoria, South Africa, 2013; Available online: http://www.up.ac.za/media/shared/Legacy/ sitefiles / file/40/677/wp_2013_15.pdf (accessed on 18 September 2020).

29. Ikhide, E.; Adjasi, C. The causal relationship between renewable and non-renewable energy consumption and economic growth: The case study of Nigeria. In Proceedings of the Economic Society of South Africa at UCT, Cape Town, South Africa, 2-4 September 2013.

30. Burakov, D.; Freidin, M. Financial development, economic growth and renewable energy consumption in Russia: A vector error correction approach. Int. J. Energy Econ. Policy 2017, 7, 39-47.

31. Lee, J.W. The contribution of foreign direct investment to clean energy use, carbon emissions and economic growth. Energy Policy 2013, 55, 483-489. [CrossRef]

32. Tiwari, A.K. Comparative performance of renewable and non-renewable energy sources on economic growth and $\mathrm{CO}_{2}$ emissions of Europe and Eurasian countries: A PVAR approach. Econ. Bull. 2011, 31, 2356-2372.

33. Cetin, M.A. Renewable energy consumption-economic growth nexus in E-7 countries. Energy Sources 2016, 11, 1180-1185. [CrossRef] 
34. Silva, S.; Soares, I.; Pinho, C. The impact of renewable energy sources on economic growth and CO2 emissions-A SVAR approach. Eur. Res. Stud. 2012, 15, 133-144. [CrossRef]

35. Marinaş, M.C.; Dinu, M.; Soco, A.G.; Cristian, S. Renewable energy consumption and economic growth: Causality relationship in Central and Eastern European countries. PLoS ONE 2018, 13, e0202951. [CrossRef]

36. Tsaurai, K.; Ngcobo, L. How relevant is financial sector development in the FDI-exports nexus in BRICS? EuroEconomica 2019, 38, 82-96.

37. Dunn, R.M.; Mutti, J.H. International Economics, 6th ed.; Routledge: Abingdon, UK, 2004; p. 544.

38. Ozcicek, O.; Agpak, F. The role of education on renewable energy use: Evidence from poisson pseudo maximum likelihood estimations. J. Bus. Econ. Policy 2017, 4, 49-61.

39. Sarkodie, S.A.; Strezov, V. Effect of foreign direct investments, economic development and energy consumption on greenhouse gas emissions in developing countries. Sci. Total Environ. 2019, 646, 862-871. [CrossRef] [PubMed]

40. Fan, W.; Yu, H. An empirical research on the relationship amongst renewable energy consumption, economic growth and foreign direct investment in China. Renew. Energy 2020, 146, 598-609. [CrossRef]

41. Dube, S. Foreign direct investment and electricity consumption on economic growth: Evidence from South Africa (Economia Internazionale). Int. Econ. 2009, 62, 175-200.

42. Tang, F.C. Electricity consumption, income, foreign direct investment, and population in Malaysia: New evidence from multivariate framework analysis. J. Econ. Stud. 2009, 36, 371-382. [CrossRef]

43. Mudakkar, S.R.; Zaman, K.; Shakir, H.; Arif, M.; Naseem, I.; Naz, L. Determinants of energy consumption function in SAARC countries: Balancing the odds. Renew. Sustain. Energy Rev. 2013, 28, 566-574. [CrossRef]

44. Azam, M.; Khan, A.Q.; Zaman, K.; Ahmad, M. Factors determining energy consumption: Evidence from Indonesia, Malaysia and Thailand. Renew. Sust. Energ. Rev. 2015, 42, 1123-1131. [CrossRef]

45. Hanif, S.M.; Faraz, R.; Gago-de-Santos, P.; Abbas, Q. Fossil fuels, foreign direct investment, and economic growth have triggered $\mathrm{CO}_{2}$ emissions in emerging Asian economies: Some empirical evidence. Energy 2019, 171, 493-501. [CrossRef]

46. Pîrlogea, C.; Cicea, C. Econometric perspective of the energy consumption and economic growth relation in European Union. Renew. Sustain. Energy Rev. 2012, 16, 5718-5726. [CrossRef]

47. Engle, R.F.; Granger, C.W.J. Co-integration and error correction representation, estimation and testing Econometrica. J. Econom. Soc. 1987, 55, 251-276. [CrossRef]

48. Granger, C.W.J. Some recent growths in a concept of causality. J. Econom. 1988, 39, 199-211. [CrossRef]

49. Maddala, G.S.; Wu, S.A. Comparative study of unit root tests with panel data and a new simple test. Oxf. Bull. Econ. Stat. 1999, 61, 631-652. [CrossRef]

50. Johansen, S. Estimation and hypothesis testing of co-integration vectors in Gaussian vector autoregressive models. Econometrica. J. Econom. Soc. 1991, 59, 1551-1580. [CrossRef]

51. Shahbaz, M.; Rahman, M.M. Foreign capital inflows-growth nexus and role of domestic financial sector: An ARDL co-integration approach for Pakistan. J. Econ. Res. 2010, 15, 207-231.

52. Bhattacharya, M.; Paramati, S.R.; Ozturk, I.; Bhattacharya, S. The effect of renewable energy consumption on economic growth: Evidence from top 38 countries. Appl. Energy 2016, 162, 733-741. [CrossRef]

53. Da Silva, P.P.; Cerqueira, A.P.; Ogbe, W. Determinants of renewable energy growth in Sub-Saharan Africa: Evidence from panel ARDL. Energy 2018, 156, 45-54. [CrossRef]

54. Lee, J.W. Long-run dynamics of renewable energy consumption on carbon emissions and economic growth in the European Union. Int. J. Sustain. Dev. World Ecol. 2019, 26, 69-78. [CrossRef]

55. Jebli, B.M.; Youssef, B.S.; Apergis, N. The dynamic linkage between renewable energy, tourism, $\mathrm{CO}_{2}$ emissions, economic growth, foreign direct investment, and trade. Lat. Am. Econ. Rev. 2019, 2, 1-2.

56. Sbia, R.; Shahbaz, M.; Hamdi, H. A contribution of foreign direct investment, clean energy, trade openness, carbon emissions and economic growth to energy demand in UAE. Econ. Model. 2014, 36, 191-197. [CrossRef]

57. Čulková, K.; Kudelas, D.; Weiss, E. Effectiveness of investment to renewable energy sources in Slovakia. Acta Montan. Slovaca 2014, 19, 65-69.

58. Zhelykh, V.; Venhryn, I.; Kozak, K.; Shapoval, S. Solar collectors integrated into transparent facades. Prod. Eng. Arch. 2020, 26, 84-87. [CrossRef]

59. Ingaldi, M.; Ulewicz, R. Problems with the Implementation of Industry 4.0 in Enterprises from the SME Sector. Sustainability 2020, 12, 217. [CrossRef]

60. Hussain, H.I.; Slusarczyk, B.; Kamarudin, F.; Thaker, H.M.T.; Szczepańska-Woszczyna, K. An investigation of an adaptive neuro-fuzzy inference system to predict the relationship among energy intensity, globalization, and financial development in major ASEAN economies. Energies 2020, 13, 850. [CrossRef]

61. Škare, M.; Tomić, D.; Stjepanović, S. Energy consumption and Green GDP in Europe: A panel cointegration analysis 2008-2016. Acta Montan. Slovaca 2020, 25, 46-56. 